\title{
NKG2D expression in CD4+ T lymphocytes as a marker of senescence in the aged immune system
}

\author{
Rebeca Alonso-Arias • Marco A. Moro-García • Antonio López-Vázquez • \\ Luis Rodrigo • José Baltar • Francisco M. Suárez García • \\ Juan J. Solano Jaurrieta • Carlos López-Larrea
}

Received: 29 July 2010 / Accepted: 6 December 2010 /Published online: 6 January 2011

(C) The Author(s) 2010. This article is published with open access at Springerlink.com

\begin{abstract}
Human aging is characterized by changes in the immune system which have a profound impact on the T-cell compartment. These changes are more frequently found in CD8+ T cells, and there are not well-defined markers of differentiation in the CD4+ subset. Typical features of cell immunosenescence are characteristics of pathologies in which the aberrant expression of NKG2D in CD4 $+\mathrm{T}$ cells has been described. To evaluate a possible age-related expression of NKG2D in CD4+ T cells, we compared their percentage in peripheral blood from 100 elderly and 50 young adults. The median percentage of CD4+ $\mathrm{NKG} 2 \mathrm{D}+$ in elders was $5.3 \%$ (interquartile range (IR): $8.74 \%$ ) versus $1.4 \%$ (IR: $1.7 \%$ ) in young subjects $\left(p<0.3 \times 10^{-10}\right)$. CD28 expression distinguished two subsets of CD4+ NKG2D+ cells with distinct functional properties and differentiation sta-
\end{abstract}

R. Alonso-Arias · M. A. Moro-García $\cdot$

A. López-Vázquez • C. López-Larrea $(\bowtie)$

Histocompatibility Unit, Immunology Department,

Hospital Universitario Central de Asturias,

33006 Oviedo, Spain

e-mail: inmuno@hca.es

L. Rodrigo

Gastroenterology Department,

Hospital Universitario Central de Asturias,

33006 Oviedo, Spain

J. Baltar

Health Outcomes Research Unit, Nephrology Department, Hospital Universitario Central de Asturias,

33006 Oviedo, Spain tus. CD28+ cells showed an immature phenotype associated with high frequencies of CD45RA and CD31. However, most of the NKG2D+ cells belonged to the $\mathrm{CD} 28^{\text {null }}$ compartment and shared their phenotypical properties. NKG2D+ cells represented a more advanced stage of maturation and exhibited greater response to CMV $(5.3 \pm 3.1 \%$ versus $3.4 \pm 2 \%, p=$ $0.037)$, higher production of IFN- $\gamma(40.56 \pm 13.7 \%$ versus $24 \pm 8.8 \%, p=0.015)$, lower activation threshold and reduced TREC content. Moreover, the frequency of the CD4+ NKG2D+ subset was clearly related to the status of the $\mathrm{T}$ cells. Higher frequencies of the NKG2D+ subset were accompanied with a gradual decrease of NAIVE and central memory cells, but also with a higher level of more differentiated subsets of CD4+ $\mathrm{T}$ cells. In conclusion, CD4+ $\mathrm{NKG} 2 \mathrm{D}+$ represent a subset of highly differentiated

F. M. S. García

Consejería de Salud y Servicios Sanitarios del Principado de Asturias,

33006 Oviedo, Spain

J. J. S. Jaurrieta

Internal Medicine and Geriatrics Department,

Hospital Monte Naranco,

33012 Oviedo, Spain

C. López-Larrea

Fundación Renal "Iñigo Alvarez de Toledo", Madrid, Spain 
$\mathrm{T}$ cells which characterizes the senescence of the immune system.

Keywords Immunosenescence $\cdot \mathrm{NKG} 2 \mathrm{D} \cdot \mathrm{CD} 4+\cdot \mathrm{T}$ lymphocytes $\cdot$ Differentiation $\cdot \mathrm{CMV}$

\section{Introduction}

The human immune system progressively deteriorates with age, which leads to a greater incidence or reactivation of infectious diseases, as well as to the development of autoimmune disorders and cancer (DelaRosa et al. 2006; Prelog 2006). These defective immune responses are also manifested in a reduced capacity to induce immunological memory to vaccines and infections. In fact, the incidence of acute transplantation rejections is significantly lower in elderly transplant patients (Bradley 2002; Deng et al. 2004; Trzonkowski et al. 2010). Thus, aging is characterized by a reduction in adaptive responses, with a profound impact on the T-cell compartment. Elders retain a relatively intact innate immunity (Pawelec et al. 1998). It is well known that the size of the thymus diminishes with age (Taub and Longo 2005). Thymic involution implies a decreased output of naïve T cells, which is evident in peripheral blood and the lymph nodes (Fagnoni et al. 2000; Sauce et al. 2009; Appay et al. 2010). In contrast, elderly donors display a marked increase in the proportion of highly differentiated effector and memory $\mathrm{T}$ cells due to a lifetime of exposure to a variety of pathogens. In the elderly, a significant proportion of $\mathrm{T}$ cells loses the expression of costimulatory molecules and acquires inhibitory receptors. $\mathrm{T}$ cells from elders exhibit reduced responses to mitogen activation, such as decreased proliferation and interleukin (IL)-2 production, and also present a short telomere length, a common property of end-stage differentiation (Effros et al. 2005; DelaRosa et al. 2006). Accumulation of these highly differentiated T cells is partially explained by their reduced susceptibility to apoptosis and their oligoclonal expansions against CMV and other chronic antigens (Vescovini et al. 2004; Almanzar et al. 2005; Vasto et al. 2007; Derhovanessian et al. 2009). The accumulation of clonal cells with pro-inflammatory capabilities and an impaired ability to distinguish "self" and "foreign" antigens may be contributing to the development of autoimmune diseases (Prelog
2006). Interestingly, the most dramatic differences between aged and young individuals have been found in the CD8+ T cell subset, whereas CD4+ T cells were more resistant to age-related phenotypic and functional changes (Olsson et al. 2000; Wikby et al. 2002; Weinberger et al. 2007; Czesnikiewicz-Guzik et al. 2008). Oligoclonal expansions within the CD4 compartment are rare, preferentially found in patients with autoimmune diseases (Schmidt et al. 1996; Thewissen et al. 2007a, b). In fact, markers of differentiation are not as well defined in CD4+ $\mathrm{T}$ cells as in CD8+ $\mathrm{T}$ cells. The diminished expression of CD28, which is frequently encountered in CD8 T cells with age, is inconsistently observed in CD4+ $\mathrm{T}$ cells (Goronzy et al. 2007; Czesnikiewicz-Guzik et al. 2008).

Cellular immunosenescence is characteristic of some pathologies in which immune activation and inflammation become generalized. In this way, some autoimmune diseases, such as rheumatoid arthritis (Thewissen et al. 2005), and some infectious diseases, such as HIV infection (Appay et al. 2007), are characterized by an accelerated immune senescent phenotype, which includes higher frequencies of the CD4+ CD28 ${ }^{\text {null }}$ subset. These CD4+ CD28 ${ }^{\text {null }}$ T cells exhibit increased effector functions and appear to amplify autoimmune and inflammatory responses. Another common property described in CD4+ T cells from patients with these pathologies is the expression of NKG2D (Groh et al. 2003; Alonso-Arias et al. 2009), a killer lectin-like receptor originally identified on NK cells, TcR $\gamma \delta+$ cells and $\mathrm{TcR} \alpha \beta+\mathrm{CD} 8+\mathrm{T}$ lymphocytes, but not on normal CD4 T cells. CD4+ NKG2D $+\mathrm{T}$ cells comprise a particular subset of CD4+ T cells which have only been described in patients with cancer, chronic autoimmune diseases, or persistent infection (Duftner et al. 2003; Azimi et al. 2006; Groh et al. 2006; Allez et al. 2007; Capraru et al. 2008; Alonso-Arias et al. 2009). Cytomegalovirus (CMV) infection, a model of antigen persistence with transient reactivations, has been associated with NKG2D expression in CD4+ T cells (Saez-Borderias et al. 2006). Mechanistically, repeated exposures to the same antigens appear to lead to NKG2D expression in CD4+ T cells and favour the differentiation of CD4+ $\mathrm{T}$ cells.

The typical features of immunosenescence and the possible association with CMV infection shared by patients with rheumatoid arthritis and patients with HIV infection prompted us to postulate a possible rise in 
the frequency of CD4+ $\mathrm{T}$ cells expressing NKG2D during aging. In this study, we describe for the first time an increased frequency of CD4+ NKG2D $+\mathrm{T}$ cells in older people and this cellular subset is strongly associated with a senescent phenotype in CD4+. These $\mathrm{NKG} 2 \mathrm{D}+$ cells present a more advanced replicative status with respect to $\mathrm{CD} 4+\mathrm{CD} 28^{\text {null }} \mathrm{T}$ cells, and NKG2D + could be a useful marker of cellular differentiation.

\section{Materials and methods}

Study population Blood samples were obtained from 100 healthy elderly donors (75 females/25 males) in the "El Cristo" Health Centre, the Hospital Universitario Central de Asturias and the Monte Naranco Hospital (Oviedo, Spain). The volunteers were not rigorously selected according to their health status in order to study a representative sample from the population. However, those volunteers with serious diseases such as cancer, chronic diseases (diabetes, autoimmune diseases), or congestive heart failure, and those receiving ongoing treatment with immunosuppressive drugs were excluded from participation. All subjects were vaccinated with a trivalent influenza vaccine (Solvay Biologicals BV, Olst, Holland). Samples from 50 young healthy controls (20 females/30 males) were obtained from the Centro de Transfusiones del Principado de Asturias (Oviedo, Spain). Inclusion criteria were a minimum age of 65 years for the elderly group and a maximum age of 55 for the young group. The mean age of the elderly individuals was $84.3 \pm$ 7.7 years (range: 68-105 years) and that of the young controls was $38.8 \pm 9.4$ years (range: $18-55$ years).

Informed consent was obtained from patients and controls prior to participating in the study. The study was approved by the Hospital Central de Asturias Ethics Committee.

CD4+ $T$ cell phenotyping The percentage of CD4+ $\mathrm{NKG} 2 \mathrm{D}+\mathrm{T}$ cells was determined in peripheral blood from both the young and elderly participants by staining with anti-CD45, anti-CD3, anti-CD4 (BD Bioscience, San Jose, CA, USA) and anti-NKG2D (eBioscience). Whole blood samples $(100 \mu \mathrm{L})$ were stained with different combinations of labelled monoclonal antibodies for $30 \mathrm{~min}$ at room temperature.
Subsequently, samples were treated with FACS Lysing Solution (BD Bioscience) to lyse red blood cells, washed in phosphate buffered saline (PBS), and analyzed with a FACSCalibur Cytometer and CellQuest software. CaliBRITE Beads (BD Biosciences, San Jose, CA, USA) were used to adjust instrument settings, set fluorescence compensation and check instrument sensitivity. BD Multicheck Control and Multicheck CD4 Low Control were used as quality controls.

Phenotypical characteristics of CD4+ NKG2D+ $\mathrm{T}$ subsets were also determined by flow cytometry. $\mathrm{CD} 4+\mathrm{T}$ cells (isolated as described below) were stained with anti-NKG2D (PE), anti-CD45RA (FITC), anti-CD45RO (PE), anti-HLA-DR (FITC), anti-CD25 (FITC), anti-CD28 (FITC or PE), and anti-CD31 (APC; BD Bioscience). Frequencies of cells with intracytoplasmic stores of granzyme B and perforin in $\mathrm{CD} 4+\mathrm{NKG} 2 \mathrm{D}+\mathrm{T}$ cells were measured. Cells were surface stained for $20 \mathrm{~min}$ at room temperature, lysed and fixed with FACS Lysing Solution, permeabilized with BD FACS Permeabilizing Solution 2 (Perm II; BD Bioscience), and stained with anti-granzyme A-FITC or anti-perforin-FITC for $30 \mathrm{~min}$ at room temperature. Cells were washed and resuspended in $1 \%$ paraformaldehyde until FACS analysis.

To analyze the differentiation status of CD4+ T cells, peripheral blood mononuclear cells (PBMC) were isolated by centrifugation on Ficoll-Hypaque gradients (Lymphoprep; Nycomed, Oslo, Norway). CD4+ T cells from young $(n=20)$ and elderly subjects with different frequencies of CD4+ NKG2D+ $(<5 \%$, $5-20 \%$ and $>20 \%, n=20$ in each group) were isolated (Myltenyi Biotec GmbH, Bergisch Gladbach, Germany) and stained with anti-CD45RA (FITC; Immunostep, Salamanca, Spain), anti-CCR7 (Alexa Fluor 647; BD Bioscience), anti-CD27 (PE; Immunostep) and anti-CD28 (PerCP; BD Bioscience).

Quantification of telomerase activity PBMC were separated from the blood of 20 elderly individuals with different levels of NKG2D expression. CD4+ T cells isolated by negative selection (Miltenyi Biotec $\mathrm{GmbH}$ ) were lysed and the protein concentration was measured in the extracts. The number of telomeric repeat sequences (TTAGGG) added to the 3 '-end of an oligonucleotide substrate was quantified using real-time PCR (ABI 7500 Real-Time PCR Systems, 
AppliedBiosystems, Carlsbad, CA, USA) using TeloExpress Quantitative Telomerase Detection Kit (XpressBio, Thurmont, MD, USA).

Antigen stimulation of whole blood cultures CMVinfected cell lysate was prepared by infecting human embryonic lung fibroblasts with the AD169 strain of CMV. Viral titers in the supernatant were determined by standard plaque assays. The virus was inactivated by repeated freeze-thaw cycles. Heparinized venous blood samples were stimulated with CMV $\left(10^{4} \mathrm{PFU} / \mathrm{mL}\right)$ or a $1 / 100$ dilution of the influenza vaccine (Solvay Biologicals BV) in $15-\mathrm{mL}$ conical polypropylene tubes. The blood cultures were incubated in humidified $37^{\circ} \mathrm{C}$ incubator for $18 \mathrm{~h}$. Activation was assessed by surface staining with anti-CD69 (eBioscience). The cells were also stained with anti-CD4, anti-CD28 and antiNKG2D. Samples were red blood cell lysed with FACS Lysing Solution, washed in PBS, and analyzed with CellQuest software.

Stimulation for cytokine assays PBMC $\left(4 \times 10^{6}\right.$ cells $/ \mathrm{mL})$ were stimulated with soluble anti-CD3 $\left(1-10^{3} \mathrm{ng} / \mathrm{mL}\right.$; eBioscience) for $6 \mathrm{~h}$. Activation was assessed by intracellular staining with anti-IFN- $\gamma$ (BD Biosciences), anti-IL-2 and anti-IL-17 (eBioscience). Cultures for the detection of intracytoplasmic cytokines were treated after the first $2 \mathrm{~h}$ with the secretion inhibitor Brefeldin A $(10 \mu \mathrm{g} / \mathrm{mL}$; Calbiochem, Darmstadt, Germany). After four additional hours, cells were treated with $2 \mathrm{mM}$ EDTA for $15 \mathrm{~min}$ at room temperature, washed, and stained with antibodies against $\mathrm{T}$ cell surface molecules at $4^{\circ} \mathrm{C}$. Intracellular staining was performed as previously described for granzyme B and perforin.

Virological testing Determination of antibodies to CMV in sera from elderly individuals was performed using the VIR-ELISA test ANTI-CMV-IgG (Viro-Immun LaborDiagnostica GmbH, Oberursel, Germany).

$T$ cell receptor excision circle quantification PBMC were separated from the blood of three elderly individuals with $>20 \% \mathrm{CD} 4+\mathrm{NKG} 2 \mathrm{D}+\mathrm{CD} 4+\mathrm{T}$ cells isolated by negative selection (Miltenyi Biotec $\mathrm{GmbH}$ ) were stained with anti-CD28-PE, and CD28+ cells were isolated with anti-PE magnetic microbeads. The negative fraction was then stained with antiNKG2D-PE and CD4+CD28 ${ }^{\text {null }} \mathrm{T}$ cells were separated into NKG2D positive and negative subsets with the aforementioned microbeads. The DNA of the isolated subsets (purity $>90 \%$ ) was extracted using a QIAamp DNA Mini Kit (Qiagen GmbH, Hilden, Germany) according to the manufacturer's instructions. Quantification of signal-joint (sj) T cell receptor excision circle (TREC) was performed by using SYBR Green real-time quantitative PCR and an iCycler thermocycler (Bio-Rad; Life Science Research Group, Hercules, CA, USA). The sequences of the utilized primers were the following: forward primer 5'-CCATGCTGACACCTCTGGTT-3', reverse primer 5'-TCGTGAGAACG GTGAATGAAG-3'. As an internal control measurement to normalize for input DNA, the $\mathrm{C} \alpha$ constant region that remains present on TCR genes despite the rearrangement processes was amplified in every sample tested (forward primer 5'-CCTGATCCTCTTGTCCCACAG-3', reverse primer 5'-GGATTT AGAGTCTCTCAGCTGGTACA-3'). Thermal cycling conditions were $50^{\circ} \mathrm{C}$ for $2 \mathrm{~min}, 95^{\circ}$ $\mathrm{C}$ for $10 \mathrm{~min}$, followed by 40 cycles at $95^{\circ} \mathrm{C}$ for $15 \mathrm{~s}$ and $60^{\circ} \mathrm{C}$ for $1 \mathrm{~min}$. Experimental samples were run in duplicate and the replicate average value was taken as the sample result.

Statistical analysis Comparisons between groups were performed with the non-parametric MannWhitney $U$ method, Kruskal-Wallis test or with the Wilcoxon signed-rank test when data were not normally distributed; or with Student's $t$ test for independent or paired data. The outlier value of the $\mathrm{CD} 4+\mathrm{NKG} 2 \mathrm{D}+\mathrm{T}$ cells in normal individuals was calculated by adding 1.5 times the interquartile range (IR) to the 75 th percentile. The $\chi^{2}$ test was used to compare dichotomous variables. Analyses were performed using the SPSS 15.0 statistical software package program (SPSS Inc. Chicago, IL, USA). $P$ values of 0.05 or less were considered significant.

\section{Results}

NKG2D expression in CD4+ T cells from elderly and young individuals

To evaluate a possible age-associated expression of NKG2D in $\mathrm{CD}^{+} \mathrm{T}$ cells, we assessed the NKG2D status on CD4+ T cells in peripheral blood cells from 
100 elderly volunteers and 50 young donors (Fig. 1a). The median percentage of CD4+ T cells expressing NKG2D was almost fourfold higher in elderly volunteers $(5.3 \%$ [IR: $8.74 \%])$ than in young subjects (1.4\% [IR: 1.7\%]) (Mann-Whitney $U$ test, $p=0.3 \times$ $10^{-10}$; Fig. 1b). The size of the CD4+ NKG2D+ pool was significantly different between the age groups. Approximately $83 \%$ of the elderly individuals displayed CD4+ NKG2D+ T cell levels higher than $2.3 \%$, the 75 th percentile in control donors ( $\chi 2$ test, $p=2 \times 10^{-12}$; OR: 15.5 [CI: 6.7-35.5]). Despite the

\section{a}
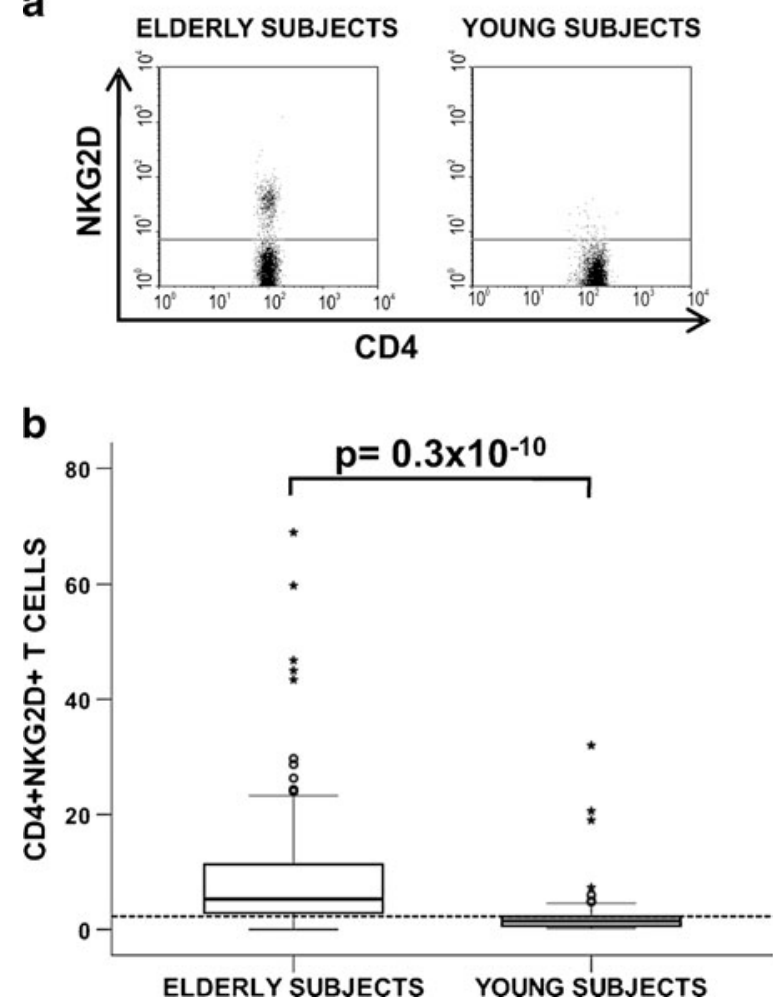

Fig. 1 CD4+ NKG2D+ T cells in peripheral blood from young and elderly individuals. (a) Representative dot plots showing the frequency of NKG2D expression in CD4+ T cells in elderly and young individuals. (b) Percentages of CD4+ T cells expressing NKG2D in a group of 100 elderly subjects compared with a group of 50 young subjects. Whole blood was stained with CD45-FITC/NKG2D-PE/CD3-PerCP/CD4-APC and $10^{5}$ cells were acquired in each experiment. Frequencies of NKG2D+ cells in gated CD45+ CD3+ CD4+ lymphocytes were analyzed. Outlier values are represented by circles and extreme values by stars, and were calculated by adding 1.5 and 3 times the IR to the 75 th percentile, respectively. The horizontal dotted line illustrates the 75 th percentile in young donors $(2.3 \%)$. The nonparametric Mann-Whitney U method was used to compare frequencies between groups decline of the absolute numbers of CD4+ T cells with age, elderly individuals also showed higher CD4+ NKG2D+ count than young subjects, with 30.7 (IR: 56.7) and 19.4 (IR: 18.4) cells per $\mu \mathrm{L}$, respectively (Mann-Whitney $U$ test, $p=0.005$ ). NKG2D-expressing CD4+ T cells were clearly more abundant in the elderly volunteers when compared with young adults.

CD4+ T cell differentiation subsets in young and elderly people related to NKG2D expression

Our studies have demonstrated that NKG2D expression in CD4 $+\mathrm{T}$ cells was clearly associated with aging; thus, NKG2D expression might represent a biomarker for differentiation and/or immunosenescence. We postulated that factors that lead to NKG2D expression can be affecting the global memory phenotype in CD4+ T lymphocytes. We studied the state of differentiation of CD4 T cells in three groups of elder individuals with different frequencies of CD4+ $\mathrm{NKG} 2 \mathrm{D}+(<5 \%, 5-20 \%$, and $>20 \% ; n=20$ in each group), and in a subset of young individuals $(n=20)$. CD4+ T cells were isolated from peripheral blood, stained with CD45RA, CCR7, CD28, and CD27 and analyzed by flow cytometry. Depending on the CD45RA and CCR7 expression, T lymphocytes were divided into naïve (NAIVE; CD45RA+CCR7+), central memory (CM; CD54RA ${ }^{-} \mathrm{CCR} 7+$ ), effector memory (EM; CD45RA ${ }^{-} \mathrm{CCR} 7^{-}$), and effector memory RA (EMRA; CD45RA+CCR7 ${ }^{-}$; Sallusto et al. 1999; Fig. 2a). A comparison between young and elderly subjects revealed a significant decrease in the frequency of NAIVE cells in the CD4+ T cell in all the NKG2D groups of elderly subjects. Moreover, an age-associated increase was found in CD4+ EM EMRA subset. The CD4+ CM subset was only significantly decreased in the $>20 \%$ NKG2D group and no differences in the EMRA subsets were found (Fig. 2b and c). The increasing NKG2D expression in the elderly was directly associated with the diminished frequencies of NAIVE and CM cells, as well as the increased EM subsets in CD4+ T cells.

EM and EMRA are heterogeneous populations, and the staining of two additional markers, CD27 and CD28, has proven useful in identifying less (CD27+ and/or $\mathrm{CD} 28+)$ or more $\left(\mathrm{CD} 27^{\text {null }} \mathrm{CD} 28^{\text {null }}\right)$ differentiated cells (Romero et al. 2007; Koch et al. 2008). In CD4+ T cells, EM T cells were divided into EM1 

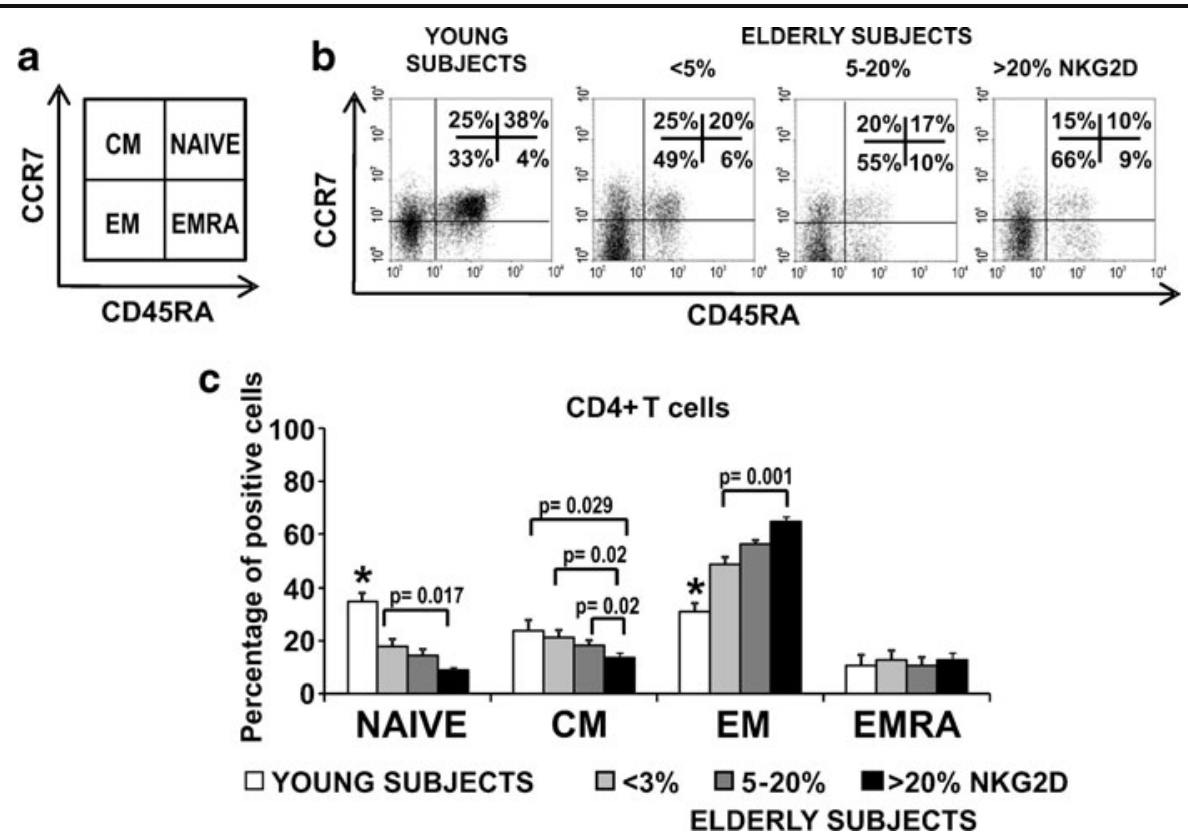

Fig. 2 Distribution of CD4+ and CD8+ T cells into naïve, central memory, effector memory, and effector memory RA. CD45RA and CCR7 expression was analysed by flow cytometry in isolated CD4 $+\mathrm{T}$ cells from young people $(n=$ $20)$ and elderly subjects with different frequencies of NKG2D $(<5 \%, 5-20 \%$, and $>20 \% ; n=20$ in each group). a Schematic model of the $\mathrm{T}$ cell differentiation subsets according to CD45RA and CCR7 expression. b Representative dot plots of

$(\mathrm{CD} 27+\mathrm{CD} 28+), \mathrm{EM} 3\left(\mathrm{CD} 27^{\text {null }} \mathrm{CD} 28^{\text {null }}\right)$, and EM4 $\left(\mathrm{CD} 27^{\text {null }} \mathrm{CD} 28+\right.$; Fig. 3a). Functionally, EM1 and EM4 are very similar and exhibit memory-like properties, whereas EM3 displayed effector-like properties. Similarly, EMRA can be divided into less differentiated $\mathrm{pE} 1(\mathrm{CD} 27+\mathrm{CD} 28+)$, and the $\mathrm{E}$ $\left(\mathrm{CD} 27^{\text {null }} \mathrm{CD} 28^{\text {null }}\right)$, the most differentiated $\mathrm{T}$ cell subset. Differentiating CD4+ T cells first lose expression of CD27 and subsequently in a later phase, they lose CD28 (Amyes et al. 2003; van Leeuwen et al. 2004). In contrast, CD $8+$ T cells first lose expression of CD28 and then CD27 (Gamadia et al. 2003).

We compared the frequencies of these subsets of CD4+ $\mathrm{T}$ cells in young subjects and the NKG2Dbased groups in elderly subjects. We found that the more differentiated subsets (EM3 and E) were increased in elderly individuals (Fig. 3b). Summarized $p$ values of these differences clearly showed that the frequency of the subsets was associated with age and CD4+ NKG2D+ cell frequency (Fig. 3c). Elderly individuals in the $<5 \%$ NKG2D group displayed only minor differences in the frequency of the subsets the subsets defined by CD45RA and CCR7 expression for individuals in each group. c Histograms depict cell percentage in each subset (mean \pm SEM) in young (white bars) and elderly subjects according to NKG2D expression (light grey bars $<5 \%$, dark grey bars $5-20 \%$, black bars $>20 \%$ ). Significant differences between subsets are indicated (Student's $t$ test or nonparametric Mann-Whitney method). Asterisks represent significant differences with all the groups $(p<0.05)$

compared with young individuals. The frequencies of the subsets in the NKG2D 5-20\% and $>20 \%$ elderly groups became increasingly different than those of the young adult group (Fig. 3c). The gradual changes in the frequencies of differentiated populations in the three NKG2D-based groups of elderly subjects in CD4+ are presented in pie charts in Fig. 3c. Significant increases in the more differentiated subsets, EM3 and $\mathrm{E}$, were observed, but decreases in the less differentiated EM1 and pE1 subsets were detected in the elderly groups. Significant differences were mainly detected between the $<5 \%$ and $>20 \%$ NKG2D groups.

To corroborate if these highly differentiated cells also display features of immunosenescence, we quantified the telomerase activity in CD4+ T cells from the three groups of elderly subjects. We found a progressive and significant reduction of the telomerase activity with the increased levels of NKG2D, with a median of $2.4 \times 10^{-5}$ amol (IR: $2.7 \times 10^{-5} \mathrm{amol}$ ) in $<5 \%, 1 \times 10^{-5} \mathrm{amol}$ (IR: $0.27 \times 10^{-5} \mathrm{amol}$ ) in $>5-20 \%$, and $0.26 \times 10^{-5} \mathrm{amol}$ (IR: $0.12 \times 10^{-5}$ amol) in $>20 \%$ NKG2D group (Kruskal-Wallis test, $p=0.008$; Fig. $3 \mathrm{~d}$ ). 
a
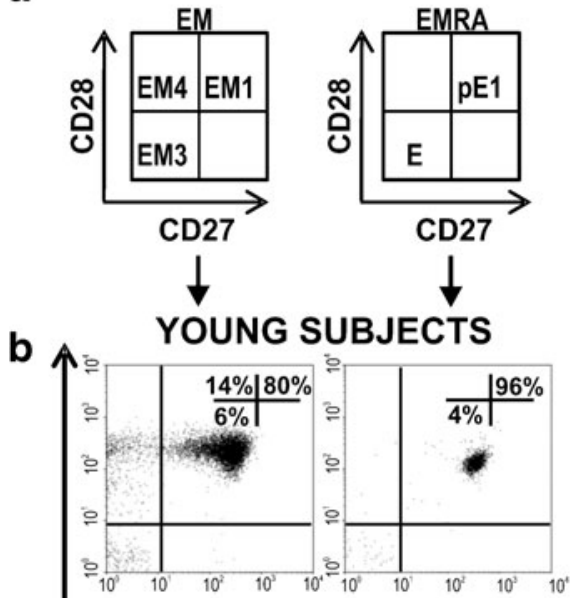

ELDERLY SUBJECTS

$<5 \%$ NKG2D

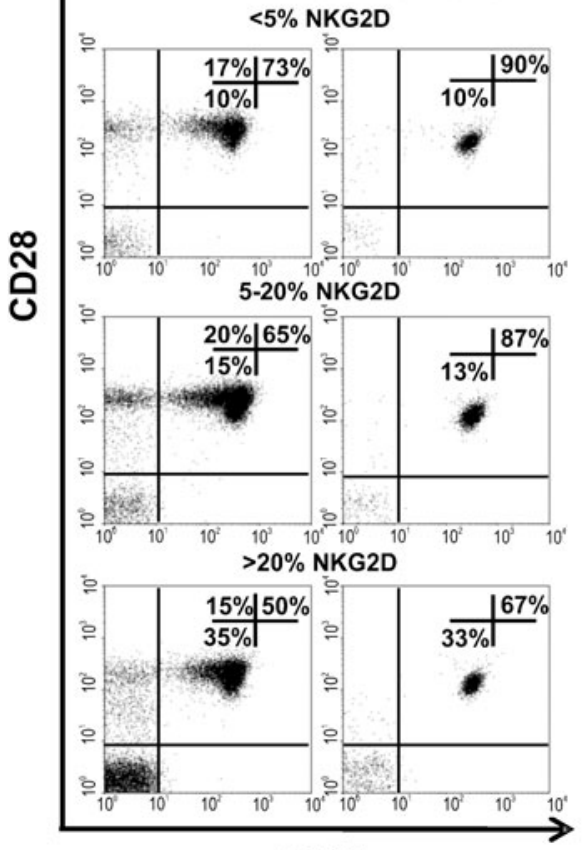

CD27

Fig. 3 Distribution of EM and EMRA CD4+ T cells into subsets defined by CD28 and CD27 expression. a Schematic model of the EM and EMRA differentiation subsets according to $\mathrm{CD} 28$ and CD27 expression. b Representative dot plots of the subsets defined by $\mathrm{CD} 27$ and CD28 expression for individuals in each group. c Individual segments of the pie charts represent the proportions of cells with each combination of CD28 and CD27 in the EM and EMRA CD4 T cell subsets in young donors $(n=20)$ and in the three NKG2D groups $(<5 \%$, $5-20 \%$, and $>20 \%$ NKG2D, $n=20$ in each group) of elderly individuals. $P$ values of differences between young and elderly people in each NKG2D group are shown in the rectangles below the pie charts (Student's $t$ test or non-parametric Mann-

C

d CD4+T cells

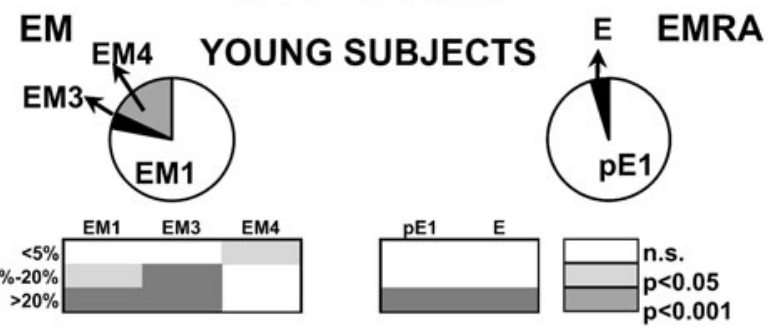

\section{ELDERLY SUBJECTS}
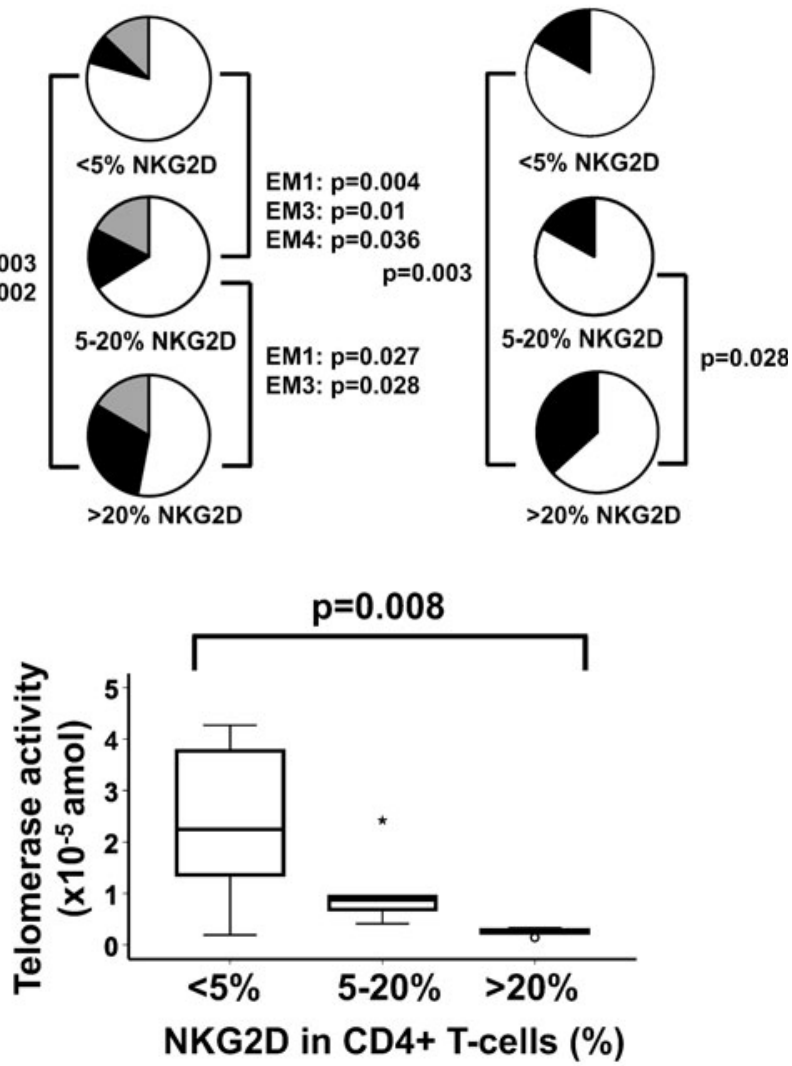

Whitney method). No significant differences were represented by white; $p<0.05$ by light grey; and $p>0.001$ by dark grey rectangles. d Quantification of telomerase activity. CD4+ T cells were isolated from eight individuals in $<5 \%$, seven in 5 $20 \%$, and five in $>20 \%$ NKG2D groups. The telomerase repeat sequence product added to the oligo substrate was determined in triplicate in the cellular extracts and the results were corrected by the total protein content. Outlier values were represented by circles and extreme values by stars, and calculated by adding 1.5 and 3 times the IR to the 75 th percentile, respectively. The non-parametric Kruskal-Wallis test was used to compare frequencies between the three groups 
In short, the frequency of the CD4+ NKG2D+ subset is clearly related to the differentiated status and the immunosenescence of the CD4+ T cell populations in the elderly. Levels of CD4+ CD28 $8^{\text {null }} \mathrm{T}$ cells did not distinguish those elders belonging to $<5 \%$ and $5-20 \%$ NKG2D groups in spite of the differences between both groups (data not shown). Thus, differences between young and elderly people are also directly related to the expression of the NKG2D marker.

\section{Characterization of CD4+ NKG2D+ T cells}

Normally, cells found in the CD4+ NKG2D+ subsetrelated pathologies had poor or no expression of CD28. Our analysis of the presence of this costimulatory receptor in elderly people revealed that most of the CD4+ NKG2D+ T cells belonged to the CD28 ${ }^{\text {null }}$ compartment, with a low proportion in the CD28 positive cells (Fig. 4a). Differences between CD4+ $\mathrm{NKG} 2 \mathrm{D}+\mathrm{T}$ cell frequencies in elderly and young people were mainly due to the $\mathrm{CD} 28^{\text {null }}$ compartment (Fig. 4a). Remarkably, the frequency of NKG2D expression in CD4+ CD28 $8^{\text {null }} \mathrm{T}$ cells was very variable, from $1.25 \%$ to $100 \%$.

CD28 expression distinguished two subsets of CD4+ $\mathrm{T}$ cells with different functional properties and differentiation status ( $\mathrm{a}$ in Fig. $4 \mathrm{~b}$ ). The majority of CD4+CD28 $8^{\text {null }} \mathrm{NKG} 2 \mathrm{D}+\mathrm{T}$ cells had a memory phenotype previously described in CD4+ CD28 null cells. These cells exhibited CD45RO and HLA-DR expression, but a diminished expression of activation marker CD25. Moreover, these CD4+ CD28 ${ }^{\text {null }}$ cells showed cytotoxic properties and had intracytoplasmic stores of granzyme $B$ and perforin $(b$ and $d$ in Fig. 4b). In contrast, the CD4+ CD28+ T cell subset showed CD25 expression but diminished HLA-DR expression and an almost absence of granzyme B and perforin (c and d Fig. 4b). This CD4+CD28+ T cell subset that expressed the NKG2D molecule displayed a naïve phenotype, with significantly higher frequencies of CD45RA $(55.7 \pm 26.6 \%)$ than the CD4+ CD28+ NKG2D ${ }^{-}$cells $(29 \pm 7.8 \%$; Student's $t$ test, $p=0.04)$. Moreover, CD4+ CD28+ $\mathrm{NKG} 2 \mathrm{D}+$ displayed an increased expression of CD31 in the CD45RA+ compartment $(74.5 \pm 11.7 \%$ versus $42.4 \pm 23 \%$, respectively; Student's $t$ test, $p=0.005$; Fig. $4 \mathrm{c}$ ).

In conclusion, $\mathrm{CD} 28$ expression distinguished two different subsets of CD4+ NKG2D+ T cells in elderly people. CD28 expressing cells predominantly showed a very immature phenotype, whereas CD28 $8^{\text {null }} \mathrm{T}$ cells mainly represented a highly differentiated, memory subset.

Activation in response to antigens

CD4+ CD28 ${ }^{\text {null }} \mathrm{T}$ lymphocytes have been described as antigen-specific cells against chronic viral antigens, and have been observed mainly in some autoimmune diseases (Thewissen et al. 2007a). In order to investigate this point in aging individuals, the response to chronic and to recent contact antigens was tested. We compared the induction of CD69 expression in response to $\mathrm{CMV}$ antigens and to influenza vaccine in CD4+ $\mathrm{T}$ cells with and without NKG2D expression from a group of 11 elderly subjects (Fig. 5). These elders were seropositive for CMV and had been recently vaccinated against the influenza virus. Their response to influenza vaccine did not show differences in the mean value of CD69 positive cells between the NKG2D+ subset at $0.6 \pm$ $0.5 \%$ and the $\mathrm{NKG}_{2} \mathrm{D}^{-}$subset at $0.9 \pm 1.2 \%$. However, there were statistically significant differences in response to CMV (paired $t$ test, $p=0.037$ ), with $5.3 \pm$ $3.1 \%$ of NKG2D+ cells expressing CD69 but only $3.4 \pm 2 \%$ of $\mathrm{NKG}_{2} \mathrm{D}^{-}$cells. Within the CD4+ CD $28+$ $\mathrm{T}$ cells, NKG2D expression did not affect the response to both CMV and influenza vaccine (data not shown). Since CMV increased NKG2D expression in CD4+ T cells (Saez-Borderias et al. 2006; Alonso-Arias et al. 2009), we analyzed the evidence of CMV infection (seropositivity) in the three groups of elder individuals with different frequencies of CD4+ NKG2D+ previously described $(<5 \%, 5-20 \%$, and $>20 \%)$. Sixteen out of the 20 individuals belonging to the $<5 \%$ NKG2D group were CMV seropositive. Furthermore, 19 of 20 volunteers in the $5-20 \%$ and $>20 \%$ groups had evidence of CMV infection. However, one seronegative individual belonged to the 5-20\% group and another seronegative participant was in the $>20 \% \mathrm{NKG} 2 \mathrm{D}+$ group. Therefore, other factors in addition to CMV infection must be implicated in the upregulation of NKG2D expression.

These results show that CD4+CD28 ${ }^{\text {null }} \mathrm{NKG} 2 \mathrm{D}+$ $\mathrm{T}$ cells displayed phenotypic properties and antigen responses typical of highly differentiated cells. Furthermore, the expression of NKG2D seemed to be partially explained by CMV infection. 
A

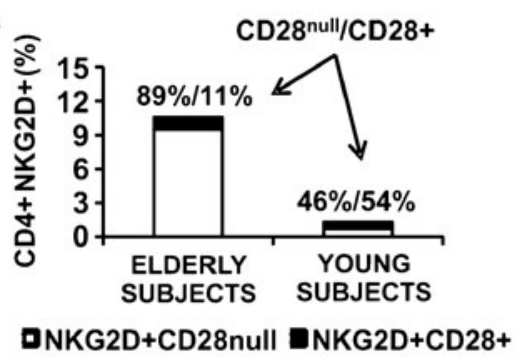

B
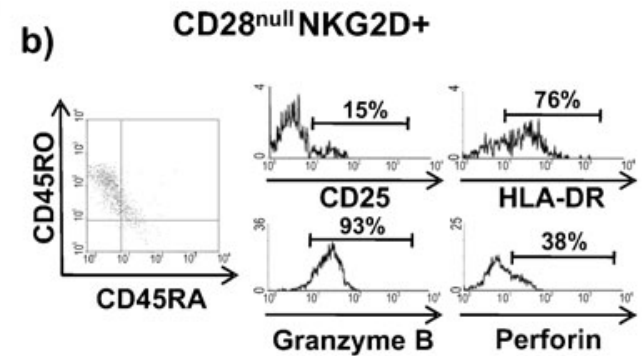

a)

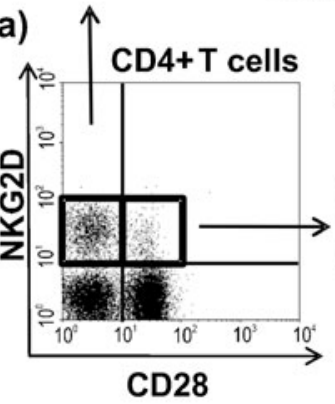

c)

CD28+NKG2D+
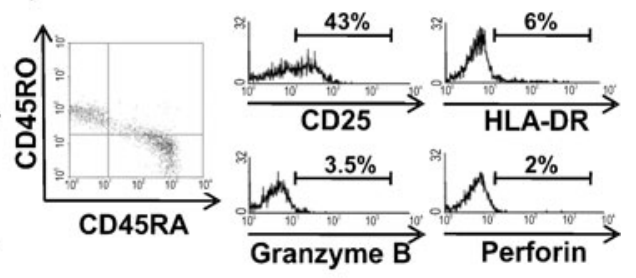
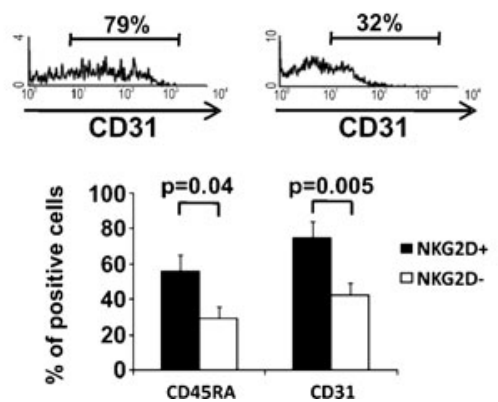

Fig. 4 Phenotypic characterization of CD4+ NKG2D+ T cells. a Expression of CD28 was analyzed in CD4+ NKG2D+ T cells from 20 elderly and 20 young individuals. Whole blood was stained with CD28-FITC/NKG2D-PE/CD3-PerCP/CD4-APC and $10^{5}$ cells were acquired in each experiment. Histograms depict the percentage of CD28+ NKG2D+ (black bar) and $\mathrm{CD} 28^{\text {null }} \mathrm{NKG} 2 \mathrm{D}+$ (white bar) cells in gated CD3+ CD4+ lymphocytes. Percentages of CD28 null and CD28+ cells within NKG2D + subset in elderly and young individuals are summarized. b $(a)$ Characterization of CD4+ NKG2D $+\mathrm{T}$ cells related to expression of the CD28 marker. (b) CD4+ T cells from five aged donors were isolated and the expression of CD45RAFITC, CD45RO-PercP, CD25-FITC, and HLA-DR-PerCP was analyzed in $\mathrm{CD} 28^{\text {null }} \mathrm{NKG} 2 \mathrm{D}+(\mathrm{Bb})$ and in $\mathrm{CD} 28+\mathrm{NKGD}+$ cells $(c)$. Intracellular staining of granzyme $\mathrm{B}$ and perforin expression. The percentages of positive cells in the indicated cell populations in this representative experiment were

Differentiation status of elderly CD4+CD28 ${ }^{\text {null }} \mathrm{T}$ cells expressing NKG2D

IL-2-expressing cells are enriched in the early differentiated subsets of CD4+ T cells, whereas IFN$\gamma$ expression is seen at all stages of differentiation, but are predominantly enriched in responses to persistent

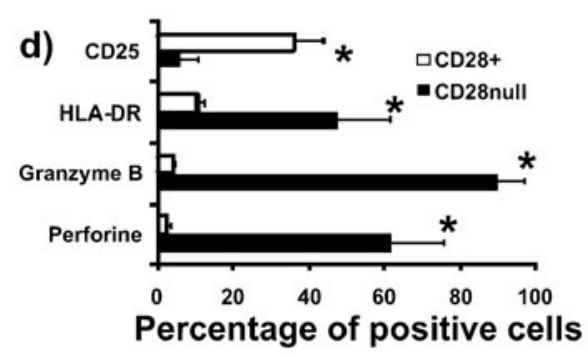

expressed in each histogram plot. (d) Histograms summarize the percentage of positive cells for each marker in $\mathrm{CD} 28^{\text {null }} \mathrm{NKG} 2 \mathrm{D}+$ and in $\mathrm{CD} 28+\mathrm{NKG} 2 \mathrm{D}+$ cells (mean \pm SEM). Asterisks significant differences between the groups ( $p$ $<0.05$ ). (Student's $t$ test or non-parametric Mann-Whitney method). (c) CD4+ $\mathrm{T}$ cells from the same donors were stained with CD45RA-FITC/NKG2D-PE/CD28-PercP/CD31-APC. The frequencies of CD45RA+ and CD31+ expression in the CD45RA subset were analyzed in CD28 + NKG2D + and in CD28+ NKG2D ${ }^{-}$subsets. The percentage of positive cells in the indicated cell populations in this representative experiment were depicted in each histogram plot. Histograms summarize the percentage of positive cells to each marker (mean \pm SEM) in $\mathrm{CD} 28+\mathrm{NKG} 2 \mathrm{D}+$ (black bars) and in $\mathrm{CD} 28+\mathrm{NKG}^{-} \mathrm{D}^{-}$cells (white bars) from five elderly donors. Student's $t$ test was used to compare means between groups

antigens and late-differentiated cells (Harari et al. 2005). Following anti-CD3 stimulation for 6 h, CD4+ CD28+ T cells produced low levels of IL-2. IL-2producing cells were not detected in the CD4+ CD2 $8^{\text {null }}$ subset (Fig. 6a). However, IFN- $\gamma$ expression was induced in a greater proportion of CD4+ CD28 $8^{\text {null }}$ (mean: $28.7 \pm 9 \%$ ) than in CD4+CD28+ T 


\section{A CD4+CD28 null}

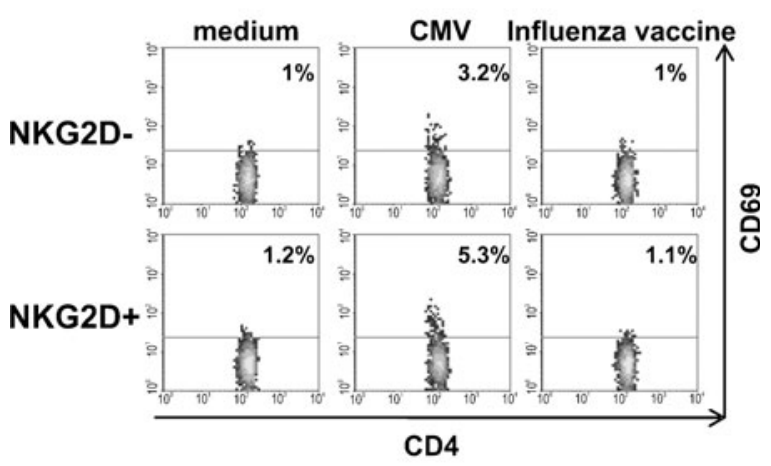

B

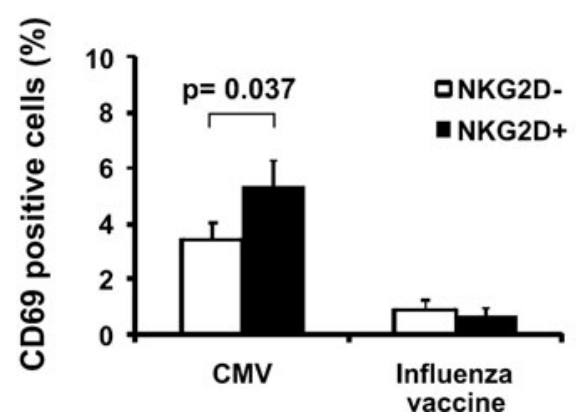

Fig. 5 CD69 expression in response to CMV antigens and to the influenza vaccine. PBMCs from elderly individuals were stimulated for $18 \mathrm{~h}$ and CD69 expression was evaluated by flow cytometry. a Representative dot plots of the frequency of CMV- and influenza vaccine-specific CD4 $\mathrm{T}$ cells with and without NKG2D expression. Percentages of positive cells in this representative experiment are expressed in dot plots. b Histograms summarize the percentage of CD69-cells positive for CMV and influenza vaccine in the CD4+CD28 ${ }^{\text {null }} \mathrm{NKG} 2 \mathrm{D}+$ (black bars) and CD4+ CD28 ${ }^{\text {null }} \mathrm{NKG} 2 \mathrm{D}$ - subsets (white bars) obtained from 11 elderly donors. Paired $t$ test was used to compare paired frequencies

cells (mean: $2.2 \pm 1.3 \%$; Fig. 6b). IFN- $\gamma$ levels showed no significant differences in CD4+ CD28+ $\mathrm{T}$ cells based in NKG2D expression. However, IFN$\gamma$ production by $\mathrm{CD} 4+\mathrm{CD} 28^{\text {null }} \mathrm{T}$ cells were significantly different in NKG2D negative $(24 \pm$ $8.8 \%)$ and NKG2D positive cells $(40.56 \pm 13.7 \%$; paired $t$ test, $p=0.015)$ of elderly participants (Fig. 6b).

$\mathrm{CD} 4+\mathrm{CD} 28^{\text {null }} \mathrm{T}$ cells presented a low activation threshold which could be implicated in its predisposition to the breakage of self-tolerance (Yung et al. 1996). In order to determine whether NKG2D status affected response threshold of CD4+ CD28 ${ }^{\text {null }} \mathrm{T}$ cells in elderly subjects, we measured the production of IFN- $\gamma$ by CD $4+$ CD28 $8^{\text {null }}$ and CD $4+$ CD28 + T cells following stimulation with $1,10,100$ and $1000 \mathrm{ng} / \mathrm{mL}$ of anti-CD3 (Fig. 6c). The dose-response curve indicated that the enhanced IFN- $\gamma$ production was elicited at concentrations as low as $1 \mathrm{ng} / \mathrm{mL}$. Anti-CD3 at $10 \mathrm{ng} / \mathrm{mL}$ stimulated maximal IFN- $\gamma$ production, while higher concentrations induced less IFN- $\gamma$. $\mathrm{CD} 28^{\text {null }} \mathrm{NKG} 2 \mathrm{D}+$ cells produced higher IFN- $\gamma$ levels than CD28 ${ }^{\text {null }}$ NKG2D ${ }^{-}$cells at all anti-CD3 concentrations tested. However, an activator effect through NKG2D stimulation was not detected. In fact, we performed antibody-dependent cytotoxicity assays with $\mathrm{CD} 4+\mathrm{NKG} 2 \mathrm{D}+\mathrm{T}$ cells isolated from peripheral blood, but ligation of NKG2D neither induced redirected lysis of P815 cells, nor enhanced lysis induced by anti-CD3 (data not shown).

Responses to low activation doses of anti-CD3 could be related to autoimmune processes frequently described in the elderly. However, we did not detect IL-17 production in CD4+ CD28 $8^{\text {null }} \mathrm{T}$ cells, regardless of NKG2D status (data not shown). Moreover, an analysis of the presence of autoantibodies, detected by indirect immunofluorescence, revealed no significant differences between individuals with or without NKG2D expression (data not shown).

Since NKG2D-expressing cells produce higher levels of IFN- $\gamma$, this subset may represent a more mature stage in the $\mathrm{CD} 4+\mathrm{CD} 28^{\text {null }} \mathrm{T}$ cells. To test differences in their replicative history, TREC content was then quantified in $\mathrm{CD} 4+\mathrm{CD} 28+, \mathrm{CD} 4+$ $\mathrm{CD} 28^{\text {null }} \mathrm{NKG}_{2} \mathrm{D}^{-}$and CD4+CD28 ${ }^{\text {null }} \mathrm{NKG} 2 \mathrm{D}+\mathrm{T}$ cell subsets isolated from three elderly individuals. TREC are episomal DNA products generated during $\mathrm{T}$ cell receptor rearrangement and not duplicated during mitosis (Hazenberg et al. 2001). Therefore, the lowest TREC content should be observed in those cells that have experienced the highest number of cell divisions. CD4+ CD28 $+\mathrm{T}$ cells displayed a higher TREC content than CD4+ CD28 ${ }^{\text {null }}$ cells (Fig. 6d). CD4+ CD28 ${ }^{\text {null }} \mathrm{NKG} 2 \mathrm{D}+$ cells had the lowest TREC content. Of note, the expression of CD57, which characterizes highly differentiated memory CD4 and CD8 T cells (Brenchley et al. 2003), displayed no significant differences in frequency between both NKG2D subsets of CD4+CD28 $8^{\text {null }}$ T cells (data not shown). Taken together, these results indicated that NKG2D expression in CD4+ CD28 ${ }^{\text {null }} \mathrm{T}$ cells was associated with high levels of IFN- $\gamma$ production and a low activation threshold. Based on TREC, the CD4+ $\mathrm{CD} 28^{\text {null }} \mathrm{NKG} 2 \mathrm{D}+$ subset in the elderly has under- 


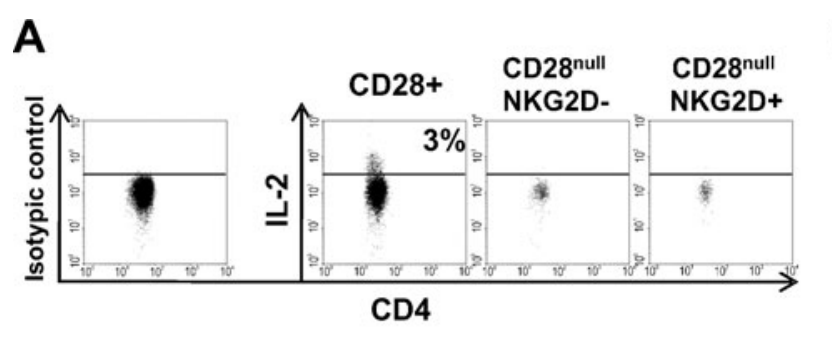

B

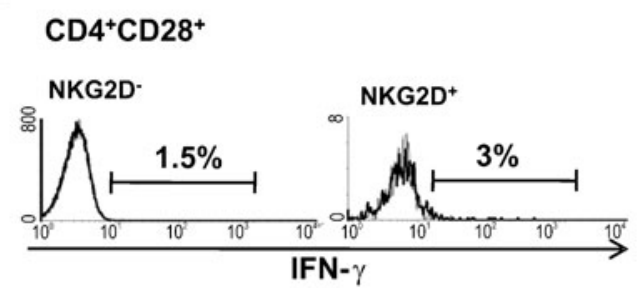

\section{CD4+CD28 null}
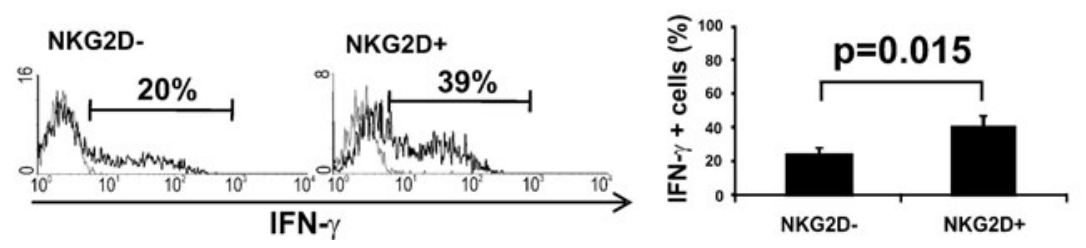

Fig. 6 Differentiated status of CD4+ subsets defined by IL-2/ IFN- $\gamma$ production and TREC content. a PBMCs were stimulated for $6 \mathrm{~h}$ with soluble anti-CD3 $(1 \mu \mathrm{g} / \mathrm{mL})$. The responder cells were analyzed for intracellular IL-2-APC staining in the indicated populations. b Cells were treated as described previously and IFN- $\gamma$ expression was analyzed by intracellular staining. Percentages of positive cells in the indicated populations in this representative experiment are expressed on the histogram-plots. Histograms summarize the percentage of IFN$\gamma$-positive cells in CD4+ CD28 $8^{\text {null }}$ and in CD4+ CD28+ lymphocytes $\mathrm{NKG} 2 \mathrm{D}-$ and $\mathrm{NKG}^{-} \mathrm{D}^{+}$(mean $\pm \mathrm{SEM}$ ) from the six elderly donors tested. A paired $t$ test was used to compare

gone more past episodes of activation and cell cycling than $\mathrm{CD} 4+\mathrm{CD} 28^{\text {null }} \mathrm{NKG} 2 \mathrm{D}^{-}$and was in the late stages of differentiation.

\section{Discussion}

We have demonstrated in this study that expression of NKG2D in CD4+ T cells is significantly increased in elderly individuals with respect to young adults. This cell subset exhibits the typical phenotype and function of end-differentiated cells which have undergone a
C

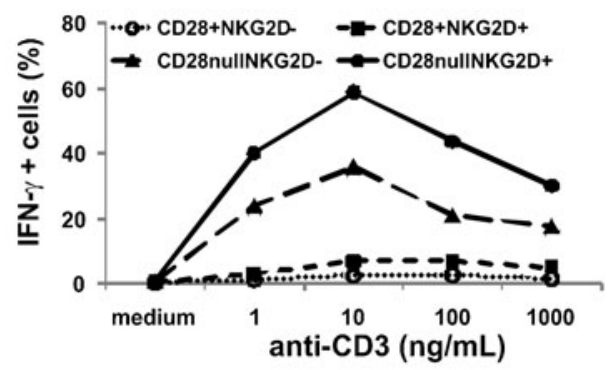

D

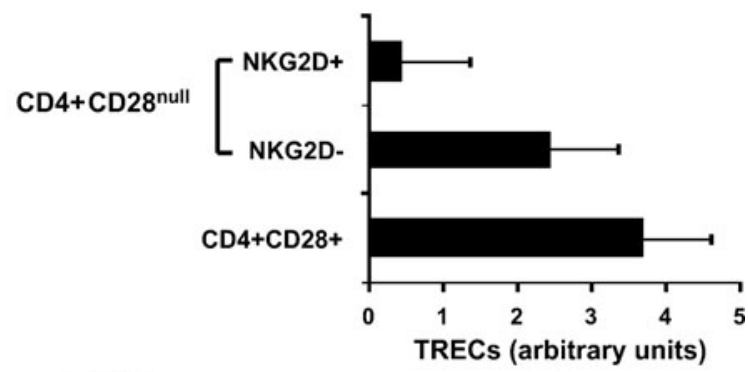

paired means. c Dose-response curves of the IFN- $\gamma$ production by CD4 subsets defined by CD28 and NKG2D expression in response to anti-CD3. The cells were cultured for $6 \mathrm{~h}$ in medium alone or with increasing concentrations of anti-CD3 $(1-1,000 \mathrm{ng} / \mathrm{mL})$. A fluorescence analysis was carried out as previously described. One representative experiment of three is shown. d Quantification of TREC copy number. CD28+, $\mathrm{CD} 28^{\text {null }} \mathrm{NKG} 2 \mathrm{D}^{-}$, and $\mathrm{CD} 28^{\text {null }} \mathrm{NKG} 2 \mathrm{D}+$ populations were isolated by sorting (magnetic bead separation) and the TREC copy number was determined by real-time PCR. Experiments were conducted in duplicate and bars represented results from three aging donors (mean \pm SEM)

high number of cell divisions. Furthermore, immune systems of donors with expansions of CD4+ NKG2D+ showed a mature phenotype in CD4+ T cells, supporting the hypothesis that NKG2D may be a useful marker for the evaluation of the degree of differentiation of the immune system.

Extensive research on the effect of age on immune responses clearly indicates its profound impact on the T-cell compartment (Pawelec et al. 1998, 2010). Thus, the phenotypic and functional analysis of $\mathrm{T}$ cells in elderly donors shows a significant decrease in naïve $\mathrm{T}$ cells and a marked increase in memory and effector/ 
memory $\mathrm{T}$ cells (Fagnoni et al. 2000; Effros et al. 2005; Taub and Longo 2005; Koch et al. 2008; Appay et al. 2010). These changes are less frequently described in $\mathrm{CD}^{+}$than in $\mathrm{CD}^{+} \mathrm{T}$ cells and there were no well-defined markers of differentiation in the $\mathrm{CD}^{+}{ }^{+}$subset. Towards this goal, an increased expression of NKG2D, which is almost absent in healthy young people, can be used as a marker for the aging of the immune system; this can be explained in part by the accumulation of end-differentiated effector CD4+ $\mathrm{T}$ cells. In pathologies such as rheumatoid arthritis (Groh et al. 2003) and HIV infection (AlonsoArias et al. 2009), the expansion of the CD4+ $\mathrm{NKG} 2 \mathrm{D}+\mathrm{T}$ cells has been associated with chronic immune activation and progressive differentiation. The extensive differentiation can limit the naïve $\mathrm{T}$ cell repertoire and reduce the ability to elicit protective immunological responses (Fasth et al. 2007; Thewissen et al. 2007a). Interestingly, the $\mathrm{T}$ cell alterations observed in rheumatoid arthritis and HIV-1 infected donors are "age-inappropriate" and similar to those observed in elderly individuals (Weyand et al. 2003; Appay et al. 2007). In both pathologies, T cell immune senescence occurs prematurely, probably due to the inability to generate sufficient numbers of naïve $\mathrm{T}$ cells. In addition, inflammation and immune activation become generalized and may lead to the accumulation of highly differentiated cells over time (Weyand et al. 2003; Appay and Sauce 2008). Among these, CD4 $+\mathrm{CD} 28^{\text {null }} \mathrm{T}$ cells are identified as a consequence of chronic immune stimulation by a viral or an autoantigen, and may constitute an important amplification mechanism.

CD28 expression distinguished two subsets of $\mathrm{CD} 4+\mathrm{NKG} 2 \mathrm{D}+\mathrm{T}$ cells with different properties and differentiation status. CD28-positive cells found in young and elderly people showed a very immature phenotype, which correlated with high frequencies of CD45RA and CD31 coexpression. In accordance with their phenotypic proximity to thymocytes, the frequency of CD4+ CD31+ cells among CD45RA decreases with age (Kohler and Thiel 2009). This subset of CD4 $+\mathrm{CD} 28+\mathrm{T}$ cells may represent the "normally occurring" population of CD4+ NKG2D+ $\mathrm{T}$ cells, recently defined by Dai et al. (2009). This $\mathrm{CD} 4+\mathrm{CD} 28+$ subset is characterized by autoreactivity, an immunosuppressive function, regulatory properties, and a lack of conventional markers of antigen exposure. These results may be in line with those indicating that CD8 thymocytes upregulate NKG2D as they complete their developmental program in the thymic medulla before seeding the periphery (Hue et al. 2003). They identified NKG2D as a potential regulator of the developmental processes in $\mathrm{T}$ cells which are essential for immune homeostasis. Of note, differences between elderly and young people were mainly due to the $\mathrm{CD} 28^{\text {null }}$ compartment. The CD28 $8^{\text {null }} \mathrm{T}$ cells expressed a similar pattern of phenotypical markers and intracytoplasmic granzyme $B$ and perforin stores regardless of NKG2D expression. Both subsets of CD28 ${ }^{\text {null }}$ showed responder cells against CMV antigens, with higher frequencies in $\mathrm{NKG} 2 \mathrm{D}+$ cells, but no response against recent contact antigens. NKG2D expression can constitute an endstage maturation marker, since we have demonstrated that these cells display a more terminally differentiated phenotype. CD57 expression, which decorates highly differentiated memory CD4 and CD8 T cells (Appay et al. 2007, 2008), did not differ in the NKG2D subsets of CD4+CD28 $8^{\text {null }}$ T cells. However, the reduced TREC levels and the higher frequency of responder cells to CMV among NKG2D+ cells with respect to CD4+CD28 ${ }^{\text {null }} \mathrm{NKG} 2 \mathrm{D}^{-} \mathrm{T}$ cells may point to an increased proliferation against specific antigens and to a more differentiated phenotype.

This hypothesis is also supported by the enhanced ability of NKG2D+ cells to produce IFN- $\gamma$ in response to TcR stimulation. IFN- $\gamma$ expression is present at all stages of differentiation, but is mostly improved in late-differentiated cells that lack IL-2production (Yue et al. 2004; Harari et al. 2005). The dominant IFN- $\gamma$ CD4 + T cell response was associated with models of antigen persistence and high antigen levels. These data suggest the acquisition of NKG2D expression is induced by repeated exposure to the same antigens and leads to a more differentiated subset of cells (Appay et al. 2002; Snyder et al. 2004; Goronzy and Weyand 2005). For example, CMV infection represents a model of antigen persistence with transient reactivations, mainly in immunosuppressed individuals. CMV was previously associated with NKG2D expression in CD4+ T cells (SaezBorderias et al. 2006; Alonso-Arias et al. 2009). Although CMV infection may account for the high number of CD4+ NKG2D $+\mathrm{T}$ cells in many of the CMV-infected elderly subjects, it does not explain the high frequencies of CD4+ NKG2D + in individuals who were seronegative for CMV. These data suggest 
that other persistent viral infections and/or the proinflammatory cytokines produced during some infectious processes may drive their differentiation. Another possible explanation is the corroborated fact that advanced age is accompanied by a low-grade, chronic upregulation of inflammatory responses evidenced by increased serum levels of proinflammatory cytokines (IL-6, IL-15, IL-8), coagulation factors, and reactive oxygen species (Mari et al. 1995; Forsey et al. 2003; Zanni et al. 2003; Ferrucci et al. 2005; Wikby et al. 2006; Giunta et al. 2008).

Our most important finding related to NKG2D expression in CD4+ T cells is its association with a more senescent and differentiated phenotype in CD4+ $\mathrm{T}$ cells. Thus, the phenotypic analysis of $\mathrm{T}$ cells in elderly donors showed a significant decrease in naïve $\mathrm{T}$ cells and a marked increase in those with a memory or effector/memory phenotype. Correlations between CD4+ and CD8+ effector cells had been demonstrated in latent $\mathrm{CMV}$ infection in the elderly, but to our knowledge, this is the first time that NKG2D has been demonstrated as a marker of differentiation in the CD4+ T-cell compartment. We applied models that categorize the $\mathrm{T}$ cell differentiation states based on CD45RA, CCR7, CD28, and CD27 expression (Sallusto et al. 1999; Rufer et al. 2003; Romero et al. 2007). Although differences between these T cell populations in young and elderly people have already been reported, we have demonstrated that levels of NKG2D expression define the state of differentiation in CD4+ $\mathrm{T}$ cells in the elderly. Aging donors with high frequencies of CD4+ NKG2D+ exhibited a more differentiated CD4+ T-cell compartment. These more differentiated CD4+ T cells can be the result of a nonspecific effect of the pro-inflammatory environment on the differentiation state of other T cells which leads to higher frequencies of differentiated cells in individuals with higher levels of CD4+ NKG2D+. Moreover, NKG2D is correlated with the senescence status of CD4 $+\mathrm{T}$ cells, since telomerase activity was reduced progressively with the increase of NKG2D expression. When cells lack telomerase activity, telomeres shorten and are no longer protective and the cell enter this non-replicative state (Campisi 1997).

In conclusion, NKG2D expression in CD4+ T cells can be a part of the differentiation process. This phenomenon is a consequence of the successive rounds of activation throughout a lifetime the elderly have gone through, and can be accelerated by the chronic activation induced by persistent viral infections or auto-antigens.

Acknowledgments We thank Isabel Cuevas Pérez, Sonia García Baragaño, and María Jesús Redondo García for their excellent technical assistance.

This work was supported by Red de Investigación Renal (REDinREN), FIS PI080566 from Instituto "Carlos III", and PEST 08-05 from FICYT.

Open Access This article is distributed under the terms of the Creative Commons Attribution Noncommercial License which permits any noncommercial use, distribution, and reproduction in any medium, provided the original author(s) and source are credited.

\section{References}

Allez M, Tieng V, Nakazawa A, Treton X, Pacault V, Dulphy N, Caillat-Zucman S, Paul P, Gornet JM, Douay C, Ravet S, Tamouza R, Charron D, Lemann M, Mayer L, Toubert A (2007) CD4+ NKG2D+ T cells in Crohn's disease mediate inflammatory and cytotoxic responses through MICA interactions. Gastroenterology 132:2346-2358

Almanzar G, Schwaiger S, Jenewein B, Keller M, HerndlerBrandstetter D, Wurzner R, Schonitzer D, GrubeckLoebenstein B (2005) Long-term cytomegalovirus infection leads to significant changes in the composition of the CD8+ T-cell repertoire, which may be the basis for an imbalance in the cytokine production profile in elderly persons. J Virol 79:3675-3683

Alonso-Arias R, Lopez-Vazquez A, Diaz-Pena R, Sampere A, Tricas L, Asensi V, Rodrigo L, Lopez-Larrea C (2009) CD8dim and NKG2D expression defines related subsets of CD4+ T cells in HIV-infected patients with worse prognostic factors. J Acquir Immune Defic Syndr 51:390-398

Amyes E, Hatton C, Montamat-Sicotte D, Gudgeon N, Rickinson AB, McMichael AJ, Callan MF (2003) Characterization of the CD4+ T cell response to Epstein-Barr virus during primary and persistent infection. J Exp Med 198:903-911

Appay V, Sauce D (2008) Immune activation and inflammation in HIV-1 infection: causes and consequences. J Pathol 214:231-241

Appay V, Zaunders JJ, Papagno L, Sutton J, Jaramillo A, Waters A, Easterbrook P, Grey P, Smith D, McMichael AJ, Cooper DA, Rowland-Jones SL, Kelleher AD (2002) Characterization of CD4(+) CTLs ex vivo. J Immunol 168:5954-5958

Appay V, Almeida JR, Sauce D, Autran B, Papagno L (2007) Accelerated immune senescence and HIV-1 infection. Exp Gerontol 42:432-437

Appay V, van Lier RA, Sallusto F, Roederer M (2008) Phenotype and function of human T lymphocyte subsets: consensus and issues. Cytom A 73:975-983

Appay V, Sauce D, Prelog M (2010) The role of the thymus in immunosenescence: lessons from the study of thymectomized individuals. Aging Albany NY 2:78-81 
Azimi N, Jacobson S, Tanaka Y, Corey L, Groh V, Spies T (2006) Immunostimulation by induced expression of NKG2D and its MIC ligands in HTLV-1-associated neurologic disease. Immunogenetics 58:252-258

Bradley BA (2002) Rejection and recipient age. Transpl Immunol 10:125-132

Brenchley JM, Karandikar NJ, Betts MR, Ambrozak DR, Hill BJ, Crotty LE, Casazza JP, Kuruppu J, Migueles SA, Connors M, Roederer M, Douek DC, Koup RA (2003) Expression of CD57 defines replicative senescence and antigen-induced apoptotic death of CD8 $+\mathrm{T}$ cells. Blood 101:2711-2720

Campisi J (1997) The biology of replicative senescence. Eur J Cancer 33:703-709

Capraru D, Muller A, Csernok E, Gross WL, Holl-Ulrich K, Northfield J, Klenerman P, Herlyn K, Holle J, Gottschlich S, Voswinkel J, Spies T, Fagin U, Jabs WJ, Lamprecht P (2008) Expansion of circulating NKG2D+ effector memory T-cells and expression of NKG2D-ligand MIC in granulomaous lesions in Wegener's granulomatosis. Clin Immunol 127:144-150

Czesnikiewicz-Guzik M, Lee WW, Cui D, Hiruma Y, Lamar DL, Yang ZZ, Ouslander JG, Weyand CM, Goronzy JJ (2008) T cell subset-specific susceptibility to aging. Clin Immunol 127:107-118

Dai Z, Turtle CJ, Booth GC, Riddell SR, Gooley TA, Stevens AM, Spies T, Groh V (2009) Normally occurring NKG2D + CD4 $+\mathrm{T}$ cells are immunosuppressive and inversely correlated with disease activity in juvenile-onset lupus. J Exp Med 206:793-805

DelaRosa O, Pawelec G, Peralbo E, Wikby A, Mariani E, Mocchegiani E, Tarazona R, Solana R (2006) Immunological biomarkers of ageing in man: changes in both innate and adaptive immunity are associated with health and longevity. Biogerontology 7:471-481

Deng Y, Jing Y, Campbell AE, Gravenstein S (2004) Agerelated impaired type $1 \mathrm{~T}$ cell responses to influenza: reduced activation ex vivo, decreased expansion in CTL culture in vitro, and blunted response to influenza vaccination in vivo in the elderly. J Immunol 172:34373446

Derhovanessian E, Larbi A, Pawelec G (2009) Biomarkers of human immunosenescence: impact of Cytomegalovirus infection. Curr Opin Immunol 21:440-445

Duftner C, Goldberger C, Falkenbach A, Wurzner R, Falkensammer B, Pfeiffer KP, Maerker-Hermann E, Schirmer M (2003) Prevalence, clinical relevance and characterization of circulating cytotoxic CD4+ CD28- T cells in ankylosing spondylitis. Arthritis Res Ther 5:R292-R300

Effros RB, Dagarag M, Spaulding C, Man J (2005) The role of CD8+ T-cell replicative senescence in human aging. Immunol Rev 205:147-157

Fagnoni FF, Vescovini R, Passeri G, Bologna G, Pedrazzoni M, Lavagetto G, Casti A, Franceschi C, Passeri M, Sansoni P (2000) Shortage of circulating naive CD8(+) $\mathrm{T}$ cells provides new insights on immunodeficiency in aging. Blood 95:2860-2868

Fasth AE, Snir O, Johansson AA, Nordmark B, Rahbar A, Af Klint E, Bjorkstrom NK, Ulfgren AK, van Vollenhoven RF, Malmstrom V, Trollmo C (2007) Skewed distribution of proinflammatory CD4+ CD28null T cells in rheumatoid arthritis. Arthritis Res Ther 9:R87

Ferrucci L, Corsi A, Lauretani F, Bandinelli S, Bartali B, Taub DD, Guralnik JM, Longo DL (2005) The origins of agerelated proinflammatory state. Blood 105:2294-2299

Forsey RJ, Thompson JM, Ernerudh J, Hurst TL, Strindhall J, Johansson B, Nilsson BO, Wikby A (2003) Plasma cytokine profiles in elderly humans. Mech Ageing Dev 124:487-493

Gamadia LE, Remmerswaal EB, Weel JF, Bemelman F, van Lier RA, Ten Berge IJ (2003) Primary immune responses to human CMV: a critical role for IFN-gamma-producing CD4+ T cells in protection against CMV disease. Blood 101:2686-2692

Giunta B, Fernandez F, Nikolic WV, Obregon D, Rrapo E, Town T, Tan J (2008) Inflammaging as a prodrome to Alzheimer's disease. J Neuroinflammation 5:51

Goronzy JJ, Weyand CM (2005) Rheumatoid arthritis. Immunol Rev 204:55-73

Goronzy JJ, Lee WW, Weyand CM (2007) Aging and T-cell diversity. Exp Gerontol 42:400-406

Groh V, Bruhl A, El-Gabalawy H, Nelson JL, Spies T (2003) Stimulation of $\mathrm{T}$ cell autoreactivity by anomalous expression of NKG2D and its MIC ligands in rheumatoid arthritis. Proc Natl Acad Sci USA 100:9452-9457

Groh V, Smythe K, Dai Z, Spies T (2006) Fas-ligand-mediated paracrine $\mathrm{T}$ cell regulation by the receptor NKG2D in tumor immunity. Nat Immunol 7:755-762

Harari A, Vallelian F, Meylan PR, Pantaleo G (2005) Functional heterogeneity of memory CD4 T cell responses in different conditions of antigen exposure and persistence. J Immunol 174:1037-1045

Hazenberg MD, Verschuren MC, Hamann D, Miedema F, van Dongen JJ (2001) T cell receptor excision circles as markers for recent thymic emigrants: basic aspects, technical approach, and guidelines for interpretation. J Mol Med 79:631-640

Hue S, Monteiro RC, Berrih-Aknin S, Caillat-Zucman S (2003) Potential role of $\mathrm{NKG} 2 \mathrm{D} / \mathrm{MHC}$ class I-related chain A interaction in intrathymic maturation of single-positive CD8 T cells. J Immunol 171:1909-1917

Koch S, Larbi A, Derhovanessian E, Ozcelik D, Naumova E, Pawelec G (2008) Multiparameter flow cytometric analysis of CD4 and CD8 T cell subsets in young and old people. Immun Ageing 5:6

Kohler S, Thiel A (2009) Life after the thymus: CD31+ and CD31- human naive CD4+ T-cell subsets. Blood 113:769-774

Mari D, Mannucci PM, Coppola R, Bottasso B, Bauer KA, Rosenberg RD (1995) Hypercoagulability in centenarians: the paradox of successful aging. Blood 85:3144-3149

Olsson J, Wikby A, Johansson B, Lofgren S, Nilsson BO, Ferguson FG (2000) Age-related change in peripheral blood T-lymphocyte subpopulations and cytomegalovirus infection in the very old: the Swedish Longitudinal OCTO Immune Study. Mech Ageing Dev 121:187-201

Pawelec G, Solana R, Remarque E, Mariani E (1998) Impact of aging on innate immunity. J Leukoc Biol 64:703-712

Pawelec G, Larbi A, Derhovanessian E (2010) Senescence of the human immune system. J Comp Pathol 142(Suppl 1):S39-S44 
Prelog M (2006) Aging of the immune system: a risk factor for autoimmunity? Autoimmun Rev 5:136-139

Romero P, Zippelius A, Kurth I, Pittet MJ, Touvrey C, Iancu EM, Corthesy P, Devevre E, Speiser DE, Rufer N (2007) Four functionally distinct populations of human effectormemory CD8+ T lymphocytes. J Immunol 178:4112-4119

Rufer N, Zippelius A, Batard P, Pittet MJ, Kurth I, Corthesy P, Cerottini JC, Leyvraz S, Roosnek E, Nabholz M, Romero P (2003) Ex vivo characterization of human CD8+ T subsets with distinct replicative history and partial effector functions. Blood 102:1779-1787

Saez-Borderias A, Guma M, Angulo A, Bellosillo B, Pende D, Lopez-Botet M (2006) Expression and function of NKG2D in CD4+ T cells specific for human cytomegalovirus. Eur J Immunol 36:3198-3206

Sallusto F, Lenig D, Forster R, Lipp M, Lanzavecchia A (1999) Two subsets of memory $\mathrm{T}$ lymphocytes with distinct homing potentials and effector functions. Nature 401:708712

Sauce D, Larsen M, Fastenackels S, Duperrier A, Keller M, Grubeck-Loebenstein B, Ferrand C, Debre P, Sidi D, Appay V (2009) Evidence of premature immune aging in patients thymectomized during early childhood. J Clin Invest 119:3070-3078

Schmidt D, Goronzy JJ, Weyand CM (1996) CD4+ CD7CD28- $\mathrm{T}$ cells are expanded in rheumatoid arthritis and are characterized by autoreactivity. J Clin Invest 97:20272037

Snyder MR, Weyand CM, Goronzy JJ (2004) The double life of NK receptors: stimulation or co-stimulation? Trends Immunol 25:25-32

Taub DD, Longo DL (2005) Insights into thymic aging and regeneration. Immunol Rev 205:72-93

Thewissen M, Linsen L, Somers V, Geusens P, Raus J, Stinissen P (2005) Premature immunosenescence in rheumatoid arthritis and multiple sclerosis patients. Ann NY Acad Sci 1051:255-262

Thewissen M, Somers V, Hellings N, Fraussen J, Damoiseaux J, Stinissen P (2007a) CD4+ CD28null T cells in autoimmune disease: pathogenic features and decreased susceptibility to immunoregulation. J Immunol 179:65146523

Thewissen M, Somers V, Venken K, Linsen L, van Paassen P, Geusens P, Damoiseaux J, Stinissen P (2007b) Analyses of immunosenescent markers in patients with autoimmune disease. Clin Immunol 123:209-218

Trzonkowski P, Debska-Slizien A, Jankowska M, Wardowska A, Carvalho-Gaspar M, Hak L, Moszkowska G, Bzoma B, Mills N, Wood KJ, Mysliwska J, Rutkowski B (2010) Immunosenescence increases the rate of acceptance of kidney allotransplants in elderly recipients through exhaustion of CD4+ T-cells. Mech Ageing Dev 131:96-104 van Leeuwen EM, Remmerswaal EB, Vossen MT, Rowshani AT, Wertheim-van Dillen PM, van Lier RA, ten Berge IJ (2004) Emergence of a CD4+ CD28- granzyme B+, cytomegalovirus-specific $\mathrm{T}$ cell subset after recovery of primary cytomegalovirus infection. J Immunol 173:18341841

Vasto S, Colonna-Romano G, Larbi A, Wikby A, Caruso C, Pawelec G (2007) Role of persistent CMV infection in configuring $\mathrm{T}$ cell immunity in the elderly. Immun Ageing $4: 2$

Vescovini R, Telera A, Fagnoni FF, Biasini C, Medici MC, Valcavi P, di Pede P, Lucchini G, Zanlari L, Passeri G, Zanni F, Chezzi C, Franceschi C, Sansoni P (2004) Different contribution of EBV and CMV infections in very long-term carriers to age-related alterations of CD8+ T cells. Exp Gerontol 39:1233-1243

Weinberger B, Lazuardi L, Weiskirchner I, Keller M, Neuner C, Fischer KH, Neuman B, Wurzner R, Grubeck-Loebenstein B (2007) Healthy aging and latent infection with CMV lead to distinct changes in CD8+ and CD4+ T-cell subsets in the elderly. Hum Immunol 68:86-90

Weyand CM, Fulbright JW, Goronzy JJ (2003) Immunosenescence, autoimmunity, and rheumatoid arthritis. Exp Gerontol 38:833-841

Wikby A, Johansson B, Olsson J, Lofgren S, Nilsson BO, Ferguson F (2002) Expansions of peripheral blood CD8 Tlymphocyte subpopulations and an association with cytomegalovirus seropositivity in the elderly: the Swedish NONA Immune Study. Exp Gerontol 37:445-453

Wikby A, Nilsson BO, Forsey R, Thompson J, Strindhall J, Lofgren S, Ernerudh J, Pawelec G, Ferguson F, Johansson B (2006) The immune risk phenotype is associated with IL-6 in the terminal decline stage: findings from the Swedish NONA Immune Longitudinal Study of very late life functioning. Mech Ageing Dev 127:695-704

Yue FY, Kovacs CM, Dimayuga RC, Parks P, Ostrowski MA (2004) HIV-1-specific memory CD4+ T cells are phenotypically less mature than cytomegalovirus-specific memory CD4+ T cells. J Immunol 172:2476-2486

Yung R, Powers D, Johnson K, Amento E, Carr D, Laing T, Yang J, Chang S, Hemati N, Richardson B (1996) Mechanisms of drug-induced lupus. II. T cells overexpressing lymphocyte function-associated antigen 1 become autoreactive and cause a lupuslike disease in syngeneic mice. J Clin Invest 97:2866-2871

Zanni F, Vescovini R, Biasini C, Fagnoni F, Zanlari L, Telera A, Di Pede P, Passeri G, Pedrazzoni M, Passeri M, Franceschi C, Sansoni P (2003) Marked increase with age of type 1 cytokines within memory and effector/cytotoxic CD8+ T cells in humans: a contribution to understand the relationship between inflammation and immunosenescence. Exp Gerontol 38:981-987 